\title{
Hubungan Laju Penyerapan Kuning Telur dengan Pertumbuhan larva IKan MAANVIS (PTEROPHYLLUM SCALARE)
}

\author{
Soko Nuswantoro ${ }^{\mathrm{a}, *}$, Anindito Pradhana ${ }^{\mathrm{a}}$, Ruby Vidia Kusumah ${ }^{\mathrm{b}}$, Fani Fariedah ${ }^{\mathrm{a}}$ \\ ${ }^{a}$ Fakultas Perikanan dan Ilmu Kelautan, Universitas Brawijaya \\ ${ }^{\mathrm{b}}$ Balai Riset dan Budidaya Ikan Hias, Depok, Jawa Barat \\ *Koresponden penulis : sokonuswantoro@ub.ac.id
}

\begin{abstract}
Abstrak
Penelitian ini bertujuan untuk mengetahui hubungan penyerapan kuning telur ikan maanvis (Pterophyllum scalare) pada pertumbuhan larva. Usaha komoditas ikan hias mulai diminati oleh masyarakat, termasuk jenis ikan Maanvis. Indonesia menjadi salah satu eksportir ikan hias ke luar negeri. Ikan maanvis merupakan ikan yang dapat dibudidayakan dengan pemijahan alami. Pemberian pakan yang tepat dapat mengurangi cost dalam usaha pembenihan dalam fase larva. Pengamatan dilakukan terhadap embrio ikan maanvis umur 0 hari dengan parameter volume kuning telur dan panjang larva dilakukan selama 8 hari, diamati setiap 24 jam. Hasil penelitian menunjukkan volume kuning telur yang berkurang diimbangi dengan pertambahan panjangnya ukuran larva. Pada penelitian ini terdapat hubungan laju penyerapan kuning telur dengan pertambahan panjang ukuran larva.
\end{abstract}

Kata Kunci: kuning telur, pertumbuhan, Pterophyllum scalare

\begin{abstract}
Abstrak
The aim of this research was to know the correlation between absorption egg yolk Maanvis (Pterophyllum scalare) on larvae growth. Ornamental fish commodity business began to be in demand by the community, including Maanvis. Indonesia becomes one of the exporters of ornamental fish overseas. Maanvis are fish that can be cultivated with natural spawning. Proper feeding can reduce the cost of aquaculture in the larval phase. Methods in this study used maanvis embryo which observed the volume of egg yolks and larval length for 8 days, observed every 24 hours. The results showed reduced yolk volume was offset by the increase in larval size. In this study there is relationship of egg yolk absorption rate with the length of larval size increase.
\end{abstract}

Keywords: egg yolk, growth, Pterophyllum scalare

\section{PENDAHULUAN}

Ikan maanvis sudah banyak dibudidayakan. Ikan maanvis sendiri memiliki warna dan bentuk yang menarik. Ikan maanvis termasuk dalam golongan cichlidae. Beberapa ikan cichlidae dari Singapura pada tahun 1970 mulai diperkenalkan ke Indonesia, salah satunya adalah ikan maanvis. Ikan maanvis sendiri berasal dari perairan Amerika Selatan[1].

Kuning telur merupakan salah satu faktor penting dalam kehidupan larva. Kuning telur merupakan cadangan makanan bagi larva. Kuning telur merupakan cadangan pakan serta sebagai nutrient dan energi untuk tumbuh dan berkembang.
Setelah kuning telur habis, larva mulai memakan pakan yang terdapat di perairan seperti plankton. Setiap jenis larva memiliki kisaran waktu yang berbeda dalam penyerapan kuning telur hingga kuning tersebut habis[2].

Pada saat telur menetas, terdapat kuning telur untuk ikan yang digunakan untuk hidup. Kuning telur tersebut digunakan sebagai pengganti makanan untuk larva yang baru menetas. Kuning telur (yolk) pada larva digunakan untuk makanan utama sebelum alat pencernaannya terbentuk sempurna[3].

Penelitian ini bertujuan untuk mengetahui laju penyerapan kuning telur 
dan pertumbuhan pada larva ikan maanvis, sehingga kebutuhan akan pakan setelah fase kuning telur dapat ditentukan dengan tepat sesuai ukuran tubuh. Pemberian pakan yang tepat dapat mengurai biaya produksi pakan pada larva dan meningkatkan kelangsungan hidup larva ikan.

\section{BAHAN DAN METODE}

Induk yang digunakan sebanyak 10 pasang. Induk berasal dari petani ikan lokal daerah Kabupaten Bojong, Bogor, Jawa Barat. Induk-induk yang digunakan dipelihara di Laboratorium Budidaya Perairan Divisi Reproduksi Fakultas Perikanan dan Ilmu Kelautan Universitas Brawijaya, Kota Malang. Induk ikan di tempatkan pada wadah toples volume 26 liter tiap pasangnya (1:1) dengan diberi media substrat pemijahan berupa pipa paralon yang telah dijemur untuk merangsang kembali pemijahan. Pemijahan ikan maanvis menggunakan substrat paralon sebagai tempat telur menempel.
Telur hasil pemijahan kemudian ditetaskan di wadah stoples volume 26 liter, yang telah diberi aerasi dengan suhu dijaga pada kisaran $28 \pm 1^{\circ} \mathrm{C}, \mathrm{pH} 6$ dan DO 6,15 ppm.

Telur yang dihasilkan berkisar 500-1000 butir. Telur ikan maanvis akan menetas 2-3 hari setelah pemijahan.

Pengamatan larva ikan maanvis dengan cara pengambilan 3 larva pada tiaptiap akuarium dan diamati dengan menggunakan mikroskop OLYMPUS LGPS2 dengan per besaran 40x. Perhitungan volume dan panjang larva menggunakan aplikasi ImageJ. pengamatan kuning telur dan panjang larva dilakukan dari saat menetas hingga hari ke-7.

\section{HASIL DAN PEMBAHASAN}

Berdasarkan pengamatan, didapatkan data peningkatan pertumbuhan setiap harinya dan penyusutan kuning telur pada larva sebagai berikut:

Tabel 1. Data Rerata Pengamatan Volume Kuning Telur dan Pertumbuhan Larva

\begin{tabular}{ccccccc}
\hline Hari ke- & Jam & $\mathrm{L}(\mathrm{mm})$ & $\begin{array}{c}\mathrm{H} \\
(\mathrm{mm})\end{array}$ & $\mathrm{V}\left(\mathrm{mm}^{3}\right)$ & $\begin{array}{c}\text { Persentase kuning } \\
\text { telur }(\%)\end{array}$ & TL $(\mathrm{mm})$ \\
\hline 0 & 0 & 1.566 & 1.19 & 1.18 & 100 & 3.28 \\
\hline 1 & 24 & 1.504 & 1.106 & 0.98 & 82.67 & 3.99 \\
\hline 2 & 48 & 1.284 & 1.051 & 0.77 & 64 & 4.43 \\
\hline 3 & 72 & 1.1 & 0.982 & 0.57 & 48 & 5.84 \\
\hline 4 & 96 & 1.081 & 0.815 & 0.38 & 37.33 & 6.14 \\
\hline 5 & 120 & 1.047 & 0.591 & 0.19 & 18.33 & 6.10 \\
\hline 6 & 144 & 0.913 & 0.432 & 0.09 & 7.33 & 6.55 \\
\hline 7 & 168 & 0 & 0 & 0 & $0 \%$ & \\
\hline
\end{tabular}

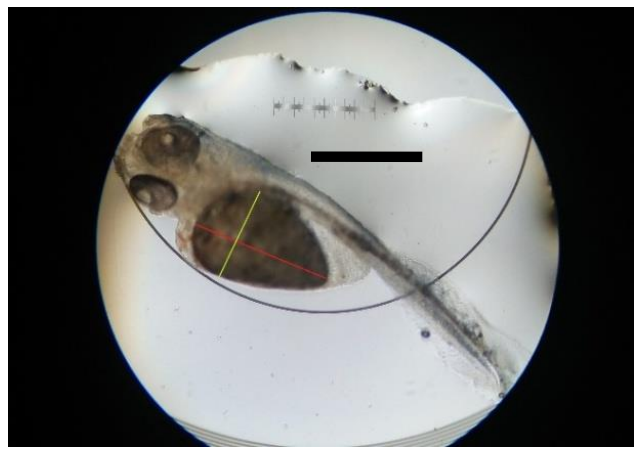

(a)

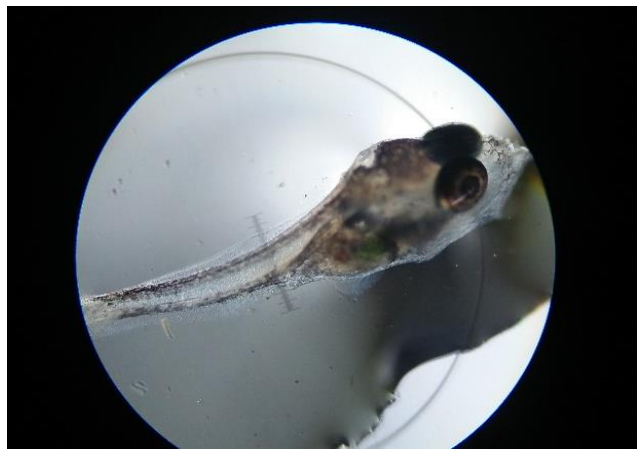

(b)

Gambar 1. Larva ikan Maanvis $\mathrm{H}_{0}$ (a), Larva ikan Maanvis $\left(\mathrm{H}_{7}\right)(\mathrm{b})$, menunjukkan $1 \mathrm{~mm}$. Per besaran 40x 
Habisnya kuning telur sebagai makanan cadangan digunakan untuk tumbuh dan berkembang[4]. Penyerapan kuning telur juga digunakan untuk metabolisme larva[5]. Hal ini menunjukkan bahwa berkurangnya volume kuning telur diimbangi dengan bertambah panjang ukuran larva. Kuning telur yang diserap digunakan untuk pertumbuhan. Selain pertumbuhan juga digunakan untuk perbaikan sel maupun jaringan di dalam tubuh yang rusak. Grafik laju penyerapan kuning telur larva ikan maanvis dapat dilihat pada grafik 1 .

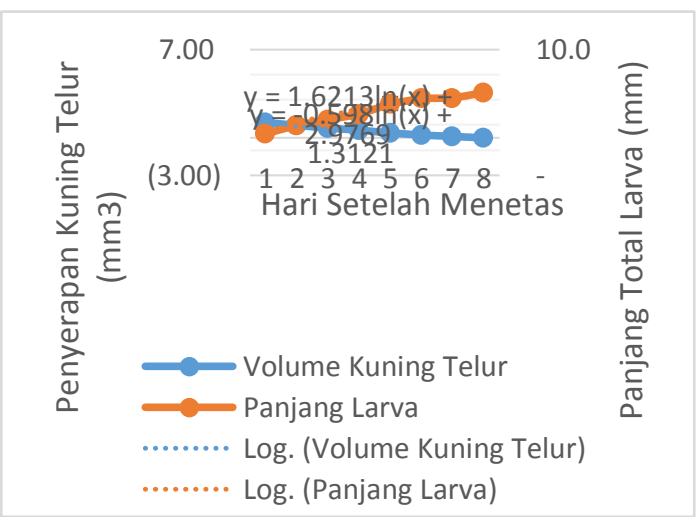

Grafik 1. Laju penyerapan kuning telur larva ikan maanvis

Dari grafik di atas didapatkan rumus laju penyerapan kuning telur dan pertumbuhan larva pada ikan.

Laju penyerapan kuning telur:

$$
y=-0.598 \ln (x)+1.3121
$$

Pertumbuhan larva ikan:

$$
y=1.6213 \ln (x)+2.9769
$$

Kuadran grafik merupakan adanya hubungan ketika grafik kurva meningkat, volume kuning telur menyusut dan grafik pertumbuhan terus meningkat, hanya saja belum dapat diketahui pola kuadratik/linear. Didapati penggunaan kuning telur tidak sepenuhnya digunakan untuk pertumbuhan, penyerapan kuning telur awalnya digunakan untuk metabolisme dan perbaikan sel dan jaringan tubuh yang rusak, lalu sisa energi digunakan untuk pertumbuhan pada larva. Pakan yang diserap pada ikan akan dijadikan energi yang dibagi untuk metabolisme, pertumbuhan, reproduksi, ekskresi dan pencernaan[6].

\section{KESIMPULAN}

Hasil dari pengamatan laju penyerapan kuning telur dengan hubungan pertumbuhan larva ikan maanvis adalah semakin menurunnya volume pada kuning telur, maka semakin bertambah panjangnya ukuran pada larva. Sehingga ke depannya masih dimungkinkan untuk pengamatan hubungan penyerapan kuning telur dengan pertumbuhan larva ikan maanvis dengan menggunakan metode yang lain.

\section{DAFTAR PUSTAKA}

[1] Kuncoro, R.B. 2012. Pembuatan Website Tempat Pariwisata Rumah Dome New Nglepen. Jurnal Speed. 4(1). 36-41.

[2] Budiardi, T., Cahyaningrum, $\mathrm{W}$ dan I. Effendi. 2005. Efisiensi Pemanfaatan Kuning Telur Embrio dan Larva Ikan Maanvis (Pterophyllum scalare) pada Suhu Inkubasi yang Berbeda. Jurnal Akuakultur Indonesia. 4(1). 57-61.

[3] Ghofur, M., Sugiharto, M dan R. Thomas. 2014. Efektifitas Pemberian Ekstrak Daun Sirih (Piper betle L.) terhadap Penetasan Telur Ikan Gurami (Osphronemus gourami. Lac). Jurnal ilmiah Universitas Batanghari Jambi. 14(1). 37-44.

[4] Djarijah, A.S. 2001. Budi Daya Ikan Bawal. Kanisius. Yogyakarta. 52 Hlm.

[5] Mulyani, Y. W. T., Solihin, D. D dan R. Affandi. 2015. Efisiensi penyerapan kuning telur dan morfogenesis pralarva ikan arwana silver Osteoglossum bicirrhosum (Cuvier, 1829) pada berbagai Interaksi Suhu dan Salinitas. Jurnal Iktiologi Indonesia. 15(3). 179-191.

[6] Cyrino, J.E.P., Bureau, D.P dan B.G. Kapoor. 2008. Feeding and Digestive Functions of Fishes. CRC Press. Boca Raton. 567 Hlm. 